\title{
From Brand Identity to Brand Equity: A Multilevel Analysis of the Organization- Employee Bidirectional Effects in Upscale Hotels
}

\begin{abstract}
:
Purpose: This study examines the mechanism of how hotel executive brand identity influences physical facility quality and customer-based brand equity (CBBE) and employeebased brand equity (EBBE).

Design: The study introduces a multilevel model and collects 925 executive and 1,978 employee responses from 62 upscale hotels in China.

Findings: Executive brand identity positively affects employee brand internalization, which leads to positive EBBE. Meanwhile, executive brand identity positively influences the physical facility quality, which leads to positive CBBE.

Practical implications: Once hotel executives have a clear understanding of the brand identity, they will provide the necessary leadership in imparting the brand identity on their employees. Hotel executives must also convince owners of the value of physical facility quality to achieve a desirable CBBE.

Originality/Value: This study considers the tangible (physical facilities) and intangible (employees) elements of hotel services to comprehensively investigate the brand equity (BE) formation. By applying multilevel structural equation modeling (SEM), the study examines the bidirectional relationship between organizations and employees in the brand value transformation process.
\end{abstract}

Keywords: brand identity; customer-based brand equity; employee-based brand equity; employee brand internalization; physical facility quality; multilevel SEM 


\section{Introduction}

The competition among hospitality service brands has become increasingly intense. The increasingly fragmented market resulting from the increased knowledge and experience of consumers exacerbates the challenge of attracting and retaining customers (King, 2017). Hotel owners and managers have realized that a strong brand is at the core of their competitive advantages. Having a clear brand identity plays an essential role in the entire brand management process.

Most hotel brands strive to differentiate their products and create a unique brand identity through physical appearance (King, 2017). However, evidence of its effectiveness in bridging brand identity and brand equity $(\mathrm{BE})$ is limited. Given that the largest financial investment is often in the physical facilities, hotel owners frequently question the need and thus attempt to negotiate a low cost option with the company management when building hotels. The physical facilities are effective stimulus of customer satisfaction (Calza et al., 2020), engagement (Choi and Kandampully, 2019), emotional response (Chen et al., 2015), and loyalty (Chen et al., 2015). However, empirically verifying the importance of establishing brand-consistent physical facilities and their role in the relationship between brand identity and $\mathrm{BE}$ is imperative.

For service-dominant industries, including hospitality, high-quality services delivered by employees are a necessary antecedent of high BE nurtured among customers (Xie et al., 2014). The value of a hotel brand is transferred through interactions between employees and customers (Bai et al., 2006), given that interactions with employees are an essential channel for customers to understand brand values (de Chernatony et al., 2006). However, the emphasis of brand management has largely been externally oriented to create awareness, image, and perception among customers, and internal brand management has usually been at a low priority. Maintaining competitiveness requires collaborative efforts of all involved, including management and front-line employees, through tangible and intangible means. A clear understanding of the mechanism reflecting relationships among brand identity, physical facility quality, and BE from the perspectives of customers and employees can enable managers to develop proper strategies to manage the brand internally and externally and convince owners of the effect of their investments.

Extensive literature exists on the concepts of and relationships among brand identity, brand internalization, and BE. However, several shortcomings exist. Theoretically, hotel BE 
deserves a comprehensive investigation. From brand identity to BE, the brand value formation involves a process of value realization among organizations, employees, and customers. Understanding such a mechanism can help underpin internal and external measures to strengthen BE. Practically, the effect of intangible aspects (e.g., service quality, management trust, and marketing element) dominates the branding literature. However, the effect of the single largest investment in hotel properties, the physical facilities, has not been explicitly assessed. Methodologically, although the branding process involves cross-level interactions (e.g., between organizations and employees, employees and customers, and organizations and customers), limited studies have investigated such phenomena from a multilevel perspective with appropriate analysis techniques (Wong, 2016). Although certain branding studies have explored the effect from organizations to employees (e.g., Xie et al., 2016; Boukis and Christodoulides, 2018), few have considered the effect from employees back to organizations. Even fewer have simultaneously considered the bidirectional effects to provide a comprehensive view.

The current study considers the tangible (physical facilities) and intangible (employees) elements of hotel services to comprehensively investigate the hotel BE formation. The study has three objectives: 1) investigating the relationship among executive brand identity, physical facility quality, and customer-based BE (CBBE) at the organization level; 2) examining the relationship among brand internalization and employee-based BE (EBBE) at the employee level; and 3) analyzing the effect of executive brand identity on employee brand internalization and the effect of EBBE on organizational CBBE cross levels.

By including the aggregated (organization) and individual (employee) level concepts, this study proposes an integrated Brand Identity-Brand Equity Model from a multilevel perspective. The top-down and bottom-up effects are proposed across two levels in this brand value transformation process. This study is at the forefront of adopting multilevel analysis with structural equation modeling (SEM) in the hospitality field. Valuable insights can be generated to provide practical implications for hotel brands to develop strategies and actions with a comprehensive understanding of the BE generation mechanism.

\section{Literature Review}

A positive BE involves efforts from different levels of an organization. The brand identity of hotel executives and the brand internalization of employees play important roles in the 
creation of the overall BE. Thus, this study reviews brand identity, brand internalization, and BE to establish a theoretical foundation of the proposed model.

\section{Brand identity}

The concept of brand identity was first introduced by Kapferer (1992) and has been studied from a wide range of disciplines, which has led to a variety of definitions and conceptual frameworks. Aaker (1996, p. 68) referred to brand identity as "a unique set of brand associations that the brand strategist aspires to create or maintain." de Chernatony (2006) defined brand identity as the distinctive idea of a brand and how the brand communicates this idea to various stakeholders. Regardless of the different definitions, scholars describe brand identity as a unique set of features of the brand, including the associated idea or essential meaning (Buil et al., 2016). Emphasis has been given to the internal nature of this construct, which originates from organizations. However, numerous scholars have questioned the internal vision of organizations. Although emanating from brand managers, other actors, including employees and customers, further develop brand (da Silveira et al., 2013). Branding literature has also discussed the stability of brand identity over time. Although brand identity definitions mainly emphasize the need to maintain identity, certain scholars reconceptualize brand identity as a dynamic concept. As such, distinguishing a core identity, which comprises the central and timeless essence of the brand, and an extended identity are possible, including other dynamic dimensions that may change in light of different contexts (da Silveira et al., 2013).

\section{Brand internalization}

Brand internalization refers to "communicating the brand effectively to the employees; convincing them of its relevance and worth; and successfully linking every job in the organization to delivery of the brand essence" (Bergstrom et al., 2002, p. 135). Brand internalization is a subset of operationalizing the brand, which simply refers to the integration of the brand with all aspects of the business (Bergstrom et al., 2002). Balmer (2008) argued that an individual's identification with an organization is influenced by his/her experience in the organization and influences his/her behaviors. Tarnovskaya and de Chernatony (2011) further argued that the brand internalization process, especially across cultures, involves conceptualizing, comprehending, and activating the brand. In terms of effective strategies to 
implement brand internalization, clarity, commitment, communication, culture, and compensation facilitate the brand internalization process (Bergstrom et al., 2002).

In the hospitality context, Cheung and Baum (2018) identified five key actions, namely, explaining the brand knowledge, associating employees with the desired brand image, communicating brand message via various information channels, strengthening employees' brand awareness, and rewarding, to support the brand internalization and delivery. Qiu and Bai (2012) analyzed the process of brand internalization at organization and employee levels, with learning, transaction, and relation recognized as important mechanisms. According to Xie et al. (2016), supportive leadership can encourage employees' brand building behavior, which influences customers' positive perception of brand image in luxury hotels. King and So (2015) indicated that internal branding activities, including brand-oriented recruitment, training, and support, exert a significant influence on employees' brand understanding, which leads to their pro-brand behavior.

\section{Brand equity}

Aaker (1991) described BE as "a set of brand assets and liabilities linked to a brand...that add to or subtract from the value provided by a product or service..." (p. 15). Papasolomou and Vrontis (2006) supported that organizations with high BE show characteristics such as high brand loyalty, name awareness, perceived quality, and credibility and has strong brand associations. Kim et al. (2008) echoed that a hospitality organization with strong BE likely obtains a series of premiums, including favorable customer response to price change and brand extension, high resiliency to endure crisis situations, and high market value.

Two popular lines of BE measurement are the financial and non-financial approaches. Although a financial approach may provide a more precise valuation of the brand than the non-financial approach; financial measurements may not be useful for the organizations to formulate marketing strategies (Keller, 1993). Much attention has been paid to the nonfinancial approach, which includes $\mathrm{CBBE}$ and $\mathrm{EBBE}$. CBBE is widely recognized as the external BE evaluated by organizations and customers, whereas EBBE is called internal BE mainly assessed by employees (Baumgarth and Schmidt, 2010). Keller (2003) defined CBBE as "the differential effect that brand knowledge has on consumer response to the marketing of that brand" (p. 60). An empirical study by Hsu et al. (2012) of upscale hotels derived six dimensions of CBBE: perceived quality, brand awareness, brand image, management trust, 
brand reliability, and brand loyalty. Also in an upscale hotel context, Wong and Wickham (2015) identified various resource categories and capabilities as antecedents of CBBE. Corporate social responsibility (Martínez and Nishiyama, 2017) and authenticity perception toward experience (Lu, Gursoy, and Lu, 2015) positively affect different dimensions of CBBE, whereas cobranding may lead to BE erosion (Tasci and Guillet, 2016). In addition, value co-creation has a positive impact on a hotel's CBBE (González-Mansilla et al., 2019).

Compared with the extensive research of CBBE, investigations on EBBE are rather limited, considering its importance (Boukis and Christodoulides, 2018). Tavassoli et al. (2014) defined EBBE as "the value that a brand provides to a firm through its effects on the attitudes and behaviors of its employees" (p. 677). King and Grace (2010) proposed an EBBE model with diverse antecedents, including role clarity and brand commitment. Boukis and Christodoulides (2018) introduced the cognitive and affective routes of forming EBBE and argued that brand knowledge and identification can positively influence EBBE and further lead to brand value dissemination and customer orientation. Xiong et al. (2013) suggested that although perceived brand knowledge can contribute to EBBE, employees must see the brand as being meaningful and relevant to embrace their role as brand ambassadors.

\section{Hypotheses and model development}

Schmitt and Simonson (1997) stated that the basic elements of a brand identity include properties, products, presentations, and publications. Kapferer (2004) argued that brand identity determines tangible attributes, and physical evidence is an essential representation of brand identity (Buil et al., 2016). Thus, brand identity from the organizational perspective may directly influence companies' investment in physical facilities. For hotels, physical facilities include design, lighting, color, scent, and sound effects across different functional areas (Lockwood and Pyun, 2020). These physical facilities act as the main elements of tangible products and the necessary platforms to deliver intangible services (Line and Hanks, 2020). Thus, to ensure the successful implementation of branding strategies, physical facilities are built according to organizations' understanding of brands. As hotel executives are held accountable to and represent the owners, their views play an important role in their insistence on and owners' willingness to invest in physical facilities according to brand standards.

H1: Executive brand identity positively influences hotels' physical facility quality. 
Brands provide not only core products or services but also sensory, experiential, authentic, and aesthetical benefits (e.g., Rodríguez-López et al., 2020). Aesthetical experience can be used as a competitive advantage in highly fierce markets and brings high customer loyalty and satisfaction. Extensive literature indicates that the physical environment heavily influences CBBE, especially in terms of brand awareness (e.g., Hsu et al., 2012). In the hospitality industry, the physical environment is created by physical facilities and influences customers' perceived value of hotels (Liu and Zhao, 2010). These factors are particularly true for upscale hotels that deliver exceptional intangible services in luxurious tangible physical environment.

H2: Hotels' physical facility quality positively influences CBBE.

Xie et al. (2016) proposed that luxury hotels benefit from managers who provide supportive leadership that encourages employee brand building behaviors, positively influencing customers' brand perception. An individual employee's identification with an organization is impacted by his/her experience in the organization and influences his/her behaviors while interacting with customers (Balmer, 2008). Furthermore, de Chernatony et al. (2006) argued that brand values are communicated to employees via overt internal communications, the ripple effect from one tier of employees to the next, senior management lead by example and involvement, and human resource activities. Keller (1999) emphasized that the manner by which the brand is positioned, explained, and communicated internally influences employee brand internalization. Therefore, executive brand identity plays an important role in influencing employee brand internalization. The positive effect of executive brand identity on employee brand internalization is evident (Boukis and Christodoulides, 2018).

H3: Executive brand identity positively influences employee brand internalization.

Employee brand internalization ensures a thorough understanding of brands and high commitment to brands, representing cognitive and affective routes leading to EBBE (Boukis and Christodoulides, 2018). Punjaisri et al. (2009) stated that once employees accept the organizational goals and values, they will support pro-brand behaviors. The more companies internalize the concept and values of services, the more consistently and effectively employees would perform accordingly (Punjaisri et al., 2009). After brand internalization, 
employees become equipped with improved brand commitment, knowledge, and involvement, which lead to EBBE, and can subsequently meet or even exceed customers' expected brand value (Baumgarth and Schmidt, 2010). As brand internalization is related to individual- and organization-level factors (Qiu and Bai, 2012), both levels are proposed to assess the impact of brand internalization on EBBE. Specifically, H4a represents the relationship between employee brand internalization and EBBE with the front-line employee data only, whereas $\mathrm{H} 4 \mathrm{~b}$ proposes this relationship with multilevel or aggregated data (employee-organization data interaction).

H4a: Employee brand internalization positively influences EBBE at the individual employee level.

H4b: Employee brand internalization positively influences EBBE at the organization level.

Given the characteristics of services, such as intangibility, heterogeneity, inseparability, and variability (Kotler et al., 2017), the value of a service brand is transferred by the interactions between employees and customers (Bai et al., 2006). For customers, interactions with employees are an essential communication channel about the brand values (de Chernatony et al., 2006). Thus, employees' understanding of a brand value directly influences customers' perceptions. Baumgarth and Schmidt (2010) indicated that EBBE positively affects CBBE.

H5: EBBE positively influences CBBE.

Based on these five hypotheses, the proposed Brand Identity-Brand Equity Model is shown in Figure 1.

\section{Insert Figure 1 here.}

\section{Methods}

\section{Research context}

The study used five-star hotels in China as the research context. As of 2017, 870 five-star hotels are in operation in Mainland China (Meadin.com, 2018). However, despite the increasing number of five-star hotels, the average operating profit ratio steadily declined from 9.44\% in 2010 to $3.07 \%$ in 2015 (Meadin.com, 2017). Given the many external factors, such 
as the lack of mature and healthy market environment, tightening up of government entertainment spending, and competition from online travel agencies, that have influenced the performance of upscale hotels, branding has become an important strategy to help hotels stay competitive. Given the relatively short development history after China's open-door policy introduced in 1978, hotel branding, especially among domestic hotel brands, is yet to be well understood and implemented. Understanding executives' views of corporate brand identity and how to transfer brand value from organization to employees and customers is a burning issue faced by hotel firms.

This study used a major Chinese hotel group as the study sample, considering its management format, size, and geographic distribution of properties. Among all five-star hotels in Mainland China in 2017, 30.34\% were management contract-based, and $69.66 \%$ were self-managed. Similarly, among the 111 five-star properties of the sampled hotel groups, $36.94 \%$ were management contract-based with international brands, and $63.06 \%$ were self-managed with its own brands. Furthermore, the geographic distribution of the group's hotels was similar to the overall five-star hotel distribution in China. Therefore, all 111 five-star properties under the group comprised the sample of the study.

\section{Instrument development}

Although existing measurements of the study constructs are available in the literature, they are developed in different contexts with different cultural backgrounds and stages of economic development. Thus, their applicability to the current study required verification. A focus group was conducted for the purposes of 1) discussing the understanding of executive brand identity in five-star hotels; 2) evaluating existing measurement scales and items; and 3) identifying physical facilities that can serve as competitive advantages in brand building. The focus group included seven participants with diverse backgrounds: one general manager (five years of hotel management experience), one marketing director (19 years of hotel experience), two front-line employees (one with three years and one with 23 years of hotel experience), one loyalty club gold card member from the hotel group, one professor specialized in branding from Shanghai, and one hotel consultant engaged by a hotel under the group. The discussion lasted two and half hours.

Based on the focus group results, the measurement of brand identity was adapted from Hirvonen and Laukkane (2014) with eight items. Brand internalization was measured by 
Punjaisri and Wilson's (2017) scale with 10 items. Baumgarth and Schmidt's (2010) fouritem measurement scale, which captured the organizational perspective of the external BE, was adopted for the following reasons. First, the current study focused on the organizationemployee interaction effect of branding, hence the organizational view of the external BE fits this aim well. Second, according to Hsu's (2015) study, domestic Chinese hotel managers rated their brand performance similarly as their customers did. Therefore, organizational perspective based on managers' ratings can reflect customers' views. Third, compared with the external BE from a customer perspective, the organizational perspective is objective, considering the marketplace benchmark, financial performance, and competitor performance (Baumgarth and Schmidt, 2010). Therefore, executives' perspective of CBBE is a widely used measurement of CBBE in branding studies across different disciplines, such as financial services (Taylor et al., 2007), marketing management (Lemon et al., 2001), and business strategic studies (Baumgarth and Schmidt, 2010). Measurements of EBBE were also adapted from Baumgarth and Schmidt (2010) with eight items. Given that no standard criteria exist to measure hotel physical facilities due to heterogeneity among brands, the measurement items of physical facility quality were developed on the basis of the focus group discussion, which considers the hotel group's development standards. Ultimately, nine items were derived.

\section{Questionnaire design and pilot study}

Given that the study involved data from two groups of respondents, namely, (1) hotel executives representing the organization-level and (2) front-line staff representing employeelevel views, two questionnaires were developed. The executive questionnaire included the constructs of executive brand identity, physical facility quality, and CBBE, whereas the employee questionnaire included brand internalization and EBBE. The construct section of the questionnaires used a seven-point Likert-type scale $(1=$ strongly disagree to $7=$ strongly agree) for respondents to rate each statement on the basis of their experience in the current hotel.

The study conducted a pilot test to ensure the clarity of instructions and evaluate construct dimensionality through exploratory factor analysis (EFA). Convenience sampling was used. Among the 111 properties in the hotel group, 20 hotels from different parts of China participated in the pilot study. In each hotel, the researchers distributed 10 questionnaires to managers and 15 to front-line employees of various departments. All respondents returned 
the completed questionnaires. Data screening was carried out according to the following criteria: 1) Responses with all items rated the same score were excluded. 2) Organizationlevel questionnaire should be filled out by those holding managerial positions, and those holding front-line positions should complete the employee-level questionnaire. Mismatched questionnaires were removed. 3) Responses with unidentifiable hotel names were disqualified. After screening, 185 valid responses from managers and 289 from employees were retained.

The researchers performed EFA on each construct by using principal axis factoring extraction method, with varimax rotation. All items held satisfactory factor loadings ( $\geq 0.606)$. An acceptable Kaiser-Meyer-Olkin (KMO) value ( $>0.8)$ and a significant Bartlett's test of sphericity $(\mathrm{p}<0.000)$ were obtained for each construct. The Cronbach's alphas for the five constructs were all above 0.9, indicating favorable internal reliability for the constructs. EFA results showed that only one factor was abstracted from each of the five constructs with satisfactory reliability and validity.

\section{Sampling and data collection}

The main survey was conducted in all properties in the hotel group. For each property, an online survey link was sent to a coordinator and was further distributed to 10 executives (including general managers and directors) and 30 front-line employees (including 10 from front desk, 10 from food and beverage, and 10 from rooms). A unique code was assigned to each hotel and was used to identify executive and employee responses from the same property. To avoid multiple attempts by an individual to complete the survey, one IP address was only allowed to complete the questionnaire once. Participation was voluntary, and respondents were assured of anonymity. The data screening criteria were the same as those applied in the pilot study. Of the 1,290 invitations sent to executives, 1,010 returned valid responses. Among employees, 3,550 invitations were distributed, and 3,112 returned valid responses. After matching the data of executive and employee respondents and maintaining a minimum sample size of five executives and 15 employees in each hotel, 925 and 1,978 respondents were retained, respectively, from 62 properties for further analysis.

A normality test was conducted, and values of skewness and kurtosis were adopted to evaluate the goodness of distribution for all scale items. All skewness $(-0.288$ to -2.396$)$ and kurtosis ( -0.366 to 8.351$)$ values indicated a good normality distribution of the scores (Field, 
2013). In terms of the multivariate normality assumption, according to Central Limit Theorem, as the sample size increases, each item approaches normal distribution, and the linear combination of items should follow a normal distribution. This condition is necessary and sufficient for a joint normal distribution. Therefore, the multivariate normality assumption is satisfied as the sample size is sufficiently large.

\section{Data analysis}

As this study involves two datasets and analyses that include individual and organizational level constructs, multilevel modeling is required to provide a rigorous investigation by controlling and accounting for variance that exists at the organizational level (Wong, 2016). Multilevel models are becoming increasingly prevalent in social science research (e.g., Wong, 2016) due to the recognition that data in the real world often exist in clusters and nests, for instance, organizations and employees. Such clustering has certain serious effects and consequences for analytical results, which deserve further investigation. In the past 15 years, certain scholars have employed the hierarchical linear modeling (HLM) to address the multilevel phenomenon (Tsaur and $\mathrm{Ku}, 2019$ ), where the factor score for each construct serves as the base in regression for each dependent variable. This approach must be bared with two limitations. First, HLM estimates the relationships in the model one by one. Compared with the estimation of all paths simultaneously, the degree of freedom (df) in HLM is smaller, which influences the significance of the estimated parameters, particularly when the model is complicated with many parameters. Second, simulation results show that the use of factor scores leads to biased outcomes when the paths are not estimated simultaneously, even when the sample size is large (Devlieger and Rosseel, 2017). To address these two limitations, a rarely used multilevel SEM in the hospitality context was applied using the Mplus Version 8.2.

Descriptive analysis was conducted to compose descriptive information of all variables. Confirmatory factor analysis (CFA) was performed on the two datasets to further confirm the dimensionality of the factors. Composite reliability was calculated to examine the internal reliability of each construct. The validity was tested using convergent validity, discriminant validity, nomological validity, and overall fit indices. After a test of the measurement model, multilevel SEM was performed to simultaneously examine the proposed relationships at organization and employee levels on the basis of the proposed hypotheses. 
In multilevel SEM, the lower "within level" means the model only uses one-level data (i.e., employee level), and only employees' individual and independent effects are considered (i.e., employee brand internalization on EBBE). Meanwhile, the higher "between level" means the model involves multilevel or aggregated data (i.e., employee-organization data interaction); and the clustering effects induced by hotel property differences are considered. Regarding the data aggregation process, by using the assigned unique hotel code, executive and employee responses from the same property were matched. Within each property, executives' responses to each item were averaged, and the mean was assigned to each employee to represent hotels' executive brand identity, physical facility quality, and CBBE. Therefore, two datasets were combined into one. In the between level model, the top-down effect (the effect of executive brand identity on employee brand internalization) and bottom-up effect (the effect of EBBE on organizational CBBE) were simultaneously tested.

\section{Findings}

\section{Demographics of respondents}

Table 1 presents the demographic profiles of the respondents. The two groups share the same gender distribution. Overall, employees reported lower education level than executives.

\section{Insert Table 1 here.}

\section{Measurement model}

The study performed CFA to validate the measurement for each construct. Composite reliabilities were all above 0.73, indicating an acceptable reliability level (Bagozzi and Kimmel, 1995). The standardized item-to-factor loading magnitude should be at least 0.5 , and the factor loadings should reach the statistical significance level (Hair et al., 2010). The CFA results suggested that all factor loadings exceeded 0.73 and were statistically significant $(\mathrm{p}<$ 0.001). The study calculated the average variance extracted (AVE) for each construct, and results of the five constructs were all above 0.69 , indicating that the convergent validity was established (Hair et al., 2010). Each construct consisted of three or more items that met the baseline of favorable practices. All items and their corresponding factor loadings are shown in Table 2. 


\section{Insert Table 2 here.}

Discriminant validity examined the external dissimilarity among factors (Byrne, 2010). In this study, each of the squared correlations between any two constructs was smaller than the corresponding AVE, confirming discriminant validity. The study evaluated the nomological validity by examining the correlations among constructs that should be theoretically related (Hair et al., 2010). Correlation coefficients among the five constructs were all statistically significant at $1 \%$ level, indicating nomological validity (Table 3 ).

\section{Insert Table 3 here.}

The chi-square $\left(\chi^{2}\right)$ test assessed the closeness-of-fit between the model and the data, which equaled to 12179.191 with the df of 682 , significant at $1 \%$ level. Thus, the ratio between $\chi^{2}$ and df was 17.86 . Although the RMSEA was 0.09 , which is slightly above the cut-off value of 0.07 (Hair et al., 2010), the two other indices, CFI and TLI, equaled to 0.909 and 0.903 , respectively, which passed the cut-off value of 0.9 (Hair et al., 2010). In addition, SRMR was 0.03, lower than the cut-off value of 0.08 (Hair et al., 2010). Thus, the overall fit of the measurement model was satisfactory.

\section{Structural model}

Prior to any relationship examination, the study examined the common method variance to identify any bias induced by the measurement method. First, for the cross-level relationship testing, the researchers collected the dependent and independent variables from different sources (i.e., executives and employees). This process naturally avoids the bias of common method variance. Second, the study used Harman's single-factor score to identify the bias induced by the measurement method (Podsakoff et al., 2012). The result indicated that the total variance explained by the single factor was $40 \%$, below the cut-off point of $50 \%$, thereby indicating that common method variance did not affect the analysis results.

The study performed multilevel SEM to examine the nested effects between the organizationand employee-level relationships in the model. Although the 62 participating hotels are all under one hotel group, they carry different brands and work with different management companies. Therefore, variation in intercepts and slopes exists across hotel properties. As random effect model can capture the individual heterogeneity of each hotel (Heck, 2001), this type of analysis was employed in the present study. The maximum likelihood robust (MLR) estimated the model. MLR is a maximum likelihood estimation with robust standard 
deviation and specialized in addressing the unbalanced number of observations in each organization. The results show an overall good fit of the model. Specifically, the $\chi^{2}$ was 3304.178 ( $\mathrm{p}<0.0001$ ), df was 832 , and the $\chi 2 / \mathrm{df}$ equaled to 3.971. The RMSEA was 0.039 , below the cut-off point of 0.07 . CFI and TLI were 0.936 and 0.932 , respectively, indicating a well-fitted model. SRMR was calculated for the within- and between-level models, and the results were 0.028 and 0.111 , respectively. Figure 2 illustrates the estimated path coefficients.

\section{Insert Figure 2 here.}

At the within level, the study identified a positive effect of employee brand internalization on $\operatorname{EBBE}(\beta=1.073, \mathrm{p}<0.000)$. At the between level, executive brand identity positively affected the physical facility quality $(\beta=1.663, \mathrm{p}<0.000)$ and employee brand internalization $(\beta=0.233, p=0.081)$. Physical facility quality positively influenced CBBE $(\beta$ $=0.623, \mathrm{p}<0.000)$, and employee brand internalization positively affected $\operatorname{EBBE}(\beta=1.618$, $p<0.000)$. The effect of EBBE on CBBE was insignificant $(\beta=-0.218, p=0.359)$. As such, $\mathrm{H} 1-\mathrm{H} 4$ ( $\mathrm{a}$ and $\mathrm{b}$ ) were not rejected, whereas H5 was.

\section{Discussion and Implications}

The academia and industry realized that establishing successful brands requires not only strategies devised by organizations or actions by employees but also cross-level cooperation and synergy. However, limited research explored this interaction from the multilevel perspective with appropriate techniques. To address this gap, the current study investigated the organization-level (aggregated) and employee-level (individual) interactions by applying multilevel SEM. The results provide rich insights into theory and practice.

\section{Theoretical contributions}

The most significant theoretical contribution is the examination of the bidirectional relationship between organizations and employees in the brand value transformation process. Although relationships between organizations and employees have been explored in other disciplines, most research has emphasized the top-down effect of organizations on employees. The bottom-up effect of employees on organizations is yet well discussed. Moreover, existing studies, especially in hospitality, fail to simultaneously consider bidirectional effects and comprehensively examine the influence mechanism. As shown in 
Figure 2, executive brand identity positively affects employee brand internalization.

However, EBBE did not show a significantly positive effect on $\mathrm{CBBE}$, which challenges the literature (Baumgarth and Schmidt, 2010).

The results also indicated that employee brand internalization activities positively led to their $\mathrm{BE}$, which is consistent with the literature. After the brand internalization process, employees are equipped with improved brand commitment, knowledge, and involvement, thus leading to improved performance (e.g., Boukis and Christodoulides, 2018). By specifying the brand internalization process and its outcome, the study provided a clear view in understanding the antecedents and consequences of the internal branding process, as demanded by the literature (de Chernatony, 2006).

This study provided support for the role played by executive brand identity in influencing the physical facility quality of hotels and hence impacting the overall CBBE. The current model explains the mechanism through which the brand value flows from the understanding of decision makers to the asset investment and maintenance of hotels, and eventually transferring to the perception of end users. The model demonstrates the brand value recognition, tangiblization, and transformation process in organizations.

The model offers a multilevel perspective of the hotel BE formation process in organization and employee levels. As strategy planners and business stewards, management's brand identity shows cross-level interaction effects on organizational performance and internal branding. In particular, executive brand identity is influential to hotels' physical facility quality, which leads to CBBE. Meanwhile, the executive brand identity shows a cross-level effect on employee brand internalization, further leading to a positive EBBE.

According Baumgarth and Schmidt (2010), the achievement of desirable CBBE requires not only the buy-ins and actions of the management but also the brand value understanding, recognition, and delivery of individual employees. However, the current study does not support the effect of EBBE on CBBE. The insignificance of this effect may reflect the following issues. First, China's upscale hotel market has experienced rapid growth in volume, yet hotel operations and customers' maturity has been developing at a slow pace. The results showed that the overall external BE relies heavily on the physical facility quality, which is tangible, visible, and easy to be recognized by customers. As signaling theory argues, in an immature market, which lacks sufficient information and understanding, customers must seek observable and creditable signals to ensure service quality and overall experience (Yao et al., 
2019). Qualities of hotels are traditionally suggested by star rating, facilities, and brand affiliation, which are standardized and identifiable (Oskam and Boswijk, 2016). Second, the support of $\mathrm{H} 3$ and $\mathrm{H} 4$ shows that once employees understand the hotel identity, they can internalize the brand values and have strong cognition of the hotel's BE. However, the lack of direct relationship between $\mathrm{EBBE}$ and $\mathrm{CBBE}$ can be affected by attitudes and behaviors of employees when interacting with customers. That is, employees stop short of affective and conative expressions of those values during service delivery while recognizing the BE. As the interaction of employees with customers play a key role in BE creation (Xie et al., 2014), attitudes and behaviors not aligned with brand values cannot contribute to the formation of CBBE.

This study applied the rarely used multilevel SEM in hospitality research and provided a cross-level perspective to understand the interactive linkage between hotels and employees. Compared with the commonly used HLM, multilevel SEM is a full information method and is advanced in estimating all parameters simultaneously and resulting in unbiased estimates. It serves as a cornerstone in widening the techniques adopted by hospitality scholars and provides tremendous opportunities for exploring new models, which can lead to theory development.

\section{Practical implications}

The results of this study show that a hotel can enhance its CBBE by building a clear brand identity understanding among executives and using its physical facilities as competitive advantages. Hotel owners must have full appreciation of the brand identity to willingly adhere to the brand standards of physical facilities. Professional managers and management companies can use empirical evidence provided by this study to convince owners of the value of physical facility quality to achieve a desirable CBBE.

The model also shows the important role hotel executives play in influencing the BE perceptions of their employees and customers and the quality of physical facilities, thus the brand identity of hotels serves as the foundation of brand management. To achieve the ultimate outcome of BE, hotel executives should acquire a clear understanding of and provide support for brand value, vision, and visual identity. Therefore, hotel companies should instill management-level staff the necessary brand identity understanding and buy-in as they must lead others by example. Once they commit to brand identity, they will provide the necessary 
leadership in maintaining the physical facilities and imparting the brand identity on their employees. As good brand identity is never static, but rather dynamic and interactive (Aaker, 1996; da Silveira et al., 2013), organization should regularly evaluate their brand identity and make adjustments to keep the identity ever relevant, updated, and attractive. Based on the agreed brand identity, hotels should build and maintain their physical facilities and strengthen their employees' cognitive, affective, and conative abilities to ensure that consistent identity is being delivered to customers. This factor is particularly important for upscale hotels, of which competitive advantages normally come from elaborate physical facilities, intangible services, brand personalities, and exclusive statuses that are associated with brands.

The study also highlights the critical role employees play in forming the overall BE. Employee brand internalization helps strengthen employees' brand understanding and hence enhance EBBE. Practices such as implementing training programs with brand appropriate skills, using effective communication channels, designing attractive promotion materials for staff, and holding regular meetings to reinforce brand expectations, mission and promises should be considered to internalize brands. Theoretically, EBBE should act as a mediator that transfers brand values from organizations to customers, which can eventually lead to CBBE (Baumgarth and Schmidt, 2010). However, the findings of the present study do not support such an argument. Thus, effective internal communications regarding the accurate delivery of brand values is useful for hotels to benefit from EBBE in the future. In addition, the hospitality industry is always challenged by high employee turnover rates, which can affect the overall inconsistent and unstable EBBE and subsequently reduce the impact of EBBE on CBBE. To improve such a situation, continued investment on employee brand internalization, along with other good human capital practices to build employee engagement and emotional affiliation with the brand, can be effective ways for hotels to retain quality and like-minded employees. Approaches such as brand-related activities, communication, and briefing can instill a sense of belonging and appeal to the affect of employees and facilitate consistent customer experience creation across employees. Meanwhile, teambuilding activities, guestfor-a-day experience, and empowerment can enhance employees' brand ambassadorship behaviors and hence result in the impact on CBBE.

\section{Conclusion and Limitations}


In a service industry that involves numerous personal touchpoints and experiential interactions, internal and external brand equities are essential to the success of brands. The current study empirically tested a multilevel model, including the perspectives of organizations and employees, and examined the mechanism of how executive brand identity influences internal and external BE. The results indicated that executive brand identity positively affects employee internalization and further leads to positive internal EBBE. Meanwhile, the executive brand identity positively influences the hotel physical facility quality and then leads to a positive external CBBE. However, EBBE does not have a significant effect on CBBE. This study considered organization and employee perspectives and proposed a dynamic Brand Identity-Brand Equity Model from a multilevel standpoint. The study examined the top-down and bottom-up effects across the two levels in this brand value transformation process.

This investigation has two main limitations. First, the study took one hotel group in China as the sample. The current study encourages future research to examine the proposed model in other cultural contexts and possibly with mid-scale, budget, or other hotel categories. Second, the measurement of $\mathrm{CBBE}$ is limited. As $\mathrm{CBBE}$ is treated as an external $\mathrm{BE}$ and an organizational construct in the model, data were collected from executives, rather than customers. Investigating CBBE from a customer perspective in future research can be beneficial. A multilevel perspective involving organizations, employees, and customers is encouraged to further examine the interaction effects in brand management studies.

\section{References}

Aaker, D. (1991). Managing Brand Equity: Capitalizing on the Value of a Brand Name. New York, NY: The Free Press.

Aaker, D. (1996) Building Strong Brands. New York, NY: The Free Press.

Bagozzi, R. P., and Kimmel, S. K. (1995). "A comparison of leading theories for the prediction of goal-directed behaviours". British Journal of Social Psychology, Vol. 34 No. 4, pp.437-461.

Bai, C., Chen, Y., and Qiu, W. (2006). "Service brand internalization: A concept model and its marketing implications", Proceedings: International Conference on Service Systems and Service Management, IEEE, University of Technology of Troyes, October 25-27, pp. 750-757.

Balmer, J.M.T. (2008), "Identity based view of the corporation", European Journal of Marketing, Vol. 42 No. 9/10, pp. 879-906. 
Baumgarth, C., and Schmidt, M. (2010). "How strong is the business-to-business brand in the workforce? An empirically-tested model of 'internal brand equity' in a business-tobusiness setting”. Industrial Marketing Management, Vol. 39 No. 8, pp.1250-1260.

Bergstrom, A., Blumenthal, D., and Crothers, S. (2002). "Why internal branding matters: The case of Saab". Corporate Reputation Review, Vol. 5, No. 2-3, pp.133-142.

Boukis, A. and Christodoulides, G. (2018). "Investigating Key Antecedents and Outcomes of Employee-based Brand Equity”, European Management Review, DOI:

10.1111/emre. 12327

Buil, I., Catalán, S., and Martínez, E. (2016). "The importance of corporate brand identity in business management: An application to the UK banking sector". BRQ Business Research Quarterly, Vol. 19 No. 1, pp.3-12.

Byrne, B. M. (2010). Structural Equation Modeling with AMOS: Basic Concepts, Applications, and Programming, 2nd ed: New York: Taylor \& Francis.

Calza, F., Pagliuca, M., Risitano, M., and Sorrentino, A. (2020). "Testing moderating effects on the relationships among on-board cruise environment, satisfaction, perceived value and behavioral intentions". International Journal of Contemporary Hospitality Management. Vol. 32, No. 2, pp. 934-952.

Chen, A., Peng, N., and Hung, K. P. (2015). "The effects of luxury restaurant environments on diners' emotions and loyalty". International Journal of Contemporary Hospitality Management. Vol. 27, No. 2, pp.236-260.

Cheung, C., and Baum, T. (2018). "How to develop hotel brand internalization among hotel employees". In Handbook of Human Resource Management in the Tourism and Hospitality Industries. Edward Elgar Publishing.

Choi, H., and Kandampully, J. (2019). "The effect of atmosphere on customer engagement in upscale hotels: An application of SOR paradigm”. International Journal of Hospitality Management, Vol. 77, pp.40-50.

da Silveira, C., Lages, C., and Simoes, C. (2013). "Reconceptualizing brand identity in a dynamic environment". Journal of Business Research. Vol.66, pp.28-36.

De Chernatony, L. (2006). From Brand Vision to Brand Evaluation. Routledge.

De Chernatony, L., Cottam, S., and Segal-Horn, S. (2006). "Communicating services brands' values internally and externally". The Service Industries Journal, Vol. 26 No. 8, pp. 819-836.

Devlieger, I., and Rosseel, Y. (2017). "Factor score path analysis". Methodology. Vol. 13, pp. 31-38.

González-Mansilla, Ó., Berenguer-Contrí, G., and Serra-Cantallops, A. (2019). "The impact of value co-creation on hotel brand equity and customer satisfaction". Tourism Management, Vol. 75, pp.51-65.

Hair, J. F., Black, W. C., Babin, B. J., and Anderson, R. E. (2010). Multivariate Data Analysis, 7th ed. Upper Saddle River, NJ: Pearson Education.

Heck, R. H. (2001). "Multilevel modeling with SEM". In New Developments and Techniques in Structural Equation Modeling (pp. 109-148). Psychology Press. 
Hirvonen, S., and Laukkanen, T. (2014). Brand orientation in small firms: an empirical test of the impact on brand performance. Journal of Strategic Marketing, Vol. 22 No. 1, pp.4158.

Hsu, C. H. (2015). "Brand performance of Chinese domestic vs. international hotels: Perceptions of operators as well as domestic and foreign guests". Research in Hospitality Management, Vol. 5 No. 2, pp.123-133.

Hsu, C. H., Oh, H., and Assaf, A. G. (2012). "A customer-based brand equity model for upscale hotels”. Journal of Travel Research, Vol. 51 No. 1, pp.81-93.

Kapferer, J-N. (1992). Strategic Brand Management: New Approaches to Measuring and Managing Brand Equity, London, Kogan Page.

Kapferer, J-N. (2004). The New Strategic Brand Management: Creating and Sustaining Brand Equity Long Term, 3rd ed. London, UK: Kogan Page.

Keller, K. L. (1993). “Conceptualizing, measuring, and managing customer-based brand equity”. Journal of Marketing, Vol. 57 No. 1, pp.1-22.

Keller, K. L. (1999), "Brand mantras: Rationale, criteria and examples", Journal of Marketing Management, Vol. 15 No. 1-3, pp.43-51.

Keller, K. L. (2003). Strategic Brand Management: Building, Measuring and Managing Brand Equity. Prentice-Hall, Upper Saddle River, NJ.

Kim, W. G., Jin-Sun, B., and Kim, H. J. (2008). "Multidimensional customer-based brand equity and its consequences in midpriced hotels". Journal of Hospitality \& Tourism Research, Vol. 32 No. 2, pp.235-254.

King, C. (2017) "Brand management - standing out from the crowd: A review and research agenda for hospitality management", International Journal of Contemporary Hospitality Management, Vol. 29 No. 1, pp.115-140.

King, C., and Grace, D. (2010). "Building and measuring employee-based brand equity". European Journal of marketing, Vol. 44 No. 7/8, pp.938-971.

King, C., and So, K. K. F. (2015). "Enhancing hotel employees' brand understanding and brand-building behavior in China". Journal of Hospitality \& Tourism Research, Vol. 39 No. 4, pp.492-516.

Kotler, P., Bowen, J. T., Makens, J., and Baloglu, S. (2017). Marketing for Hospitality and Tourism. Pearson Education, Boston, MA, US.

Lemon, K. N., Rust, R. T., and Zeithaml, V. A. (2001). "What drives customer equity?". Marketing Management, Vol. 10, No. 1, pp.20-25.

Line, N. D., and Hanks, L. (2020). "A holistic model of the servicescape in fast casual dining”. International Journal of Contemporary Hospitality Management. Vol. 32, No. 1, pp. 288-306.

Liu, X. and Zhao, J. (2010). "Econo hotel, brand identity, empirical analysis". Economy and Management, Vol. 24 No. 6, pp.48-52.

Lockwood, A., and Pyun, K. (2020). “Developing a scale measuring customers' servicescape perceptions in upscale hotels". International Journal of Contemporary Hospitality Management. Vol. 32, No. 1, pp. 40-59. 
Lu, A. C. C., Gursoy, D., and Lu, C. Y. (2015). "Authenticity perceptions, brand equity and brand choice intention: The case of ethnic restaurants". International Journal of Hospitality Management, Vol. 50, pp.36-45.

Martínez, P., and Nishiyama, N. (2017). "Enhancing customer-based brand equity through CSR in the hospitality sector". International Journal of Hospitality \& Tourism Administration, DOI: 10.1080/15256480.2017.1397581

Meadin.com (2017) https://www.meadin.com/138372.html

Meadin.com (2018) https://www.meadin.com/142092.html

Oskam, J., and Boswijk, A. (2016). "Airbnb: the future of networked hospitality businesses". Journal of Tourism Futures, Vol. 2 No. 1, pp. 22-42.

Papasolomou, I., and Vrontis, D. (2006). "Using internal marketing to ignite the corporate brand: The case of the UK retail bank industry". Journal of Brand Management, Vol. 14 No. 1-2, pp.177-195.

Podsakoff, P. M., MacKenzie, S. B., and Podsakoff, N. P. (2012). "Sources of method bias in social science research and recommendations on how to control it". Annual Review of Psychology, Vol. 63, pp.539-569.

Punjaisri, K., and Wilson, A. (2017). "The role of internal branding in the delivery of employee brand promise". In Advances in Corporate Branding. Palgrave Macmillan, London.

Punjaisri, K., Evanschitzky, H., and Wilson, A. (2009). "Internal branding: an enabler of employees' brand-supporting behaviours". Journal of Service Management. Vol. 20 No. 2, pp. 209-226.

Qiu, W. and Bai, C.H. (2012). "Study on the Internalization of Tourism Brands Based on Grounded Theory: A Case of a Five-star Hotel”. Tourism Tribune, Vol. 27 No. 10, pp.46-52.

Rodríguez-López, M. E., del Barrio-García, S., and Alcántara-Pilar, J. M. (2020). "Formation of customer-based brand equity via authenticity". International Journal of Contemporary Hospitality Management. Vol. 32, No. 2, pp. 0959-6119.

Schmitt, B., and Simonson, A. (1997). Marketing Aesthetics: The Strategic Management of Brands, Identity, and Image. Free Press.

Tarnovskaya, V. V., and de Chernatony, L. (2011). "Internalising a brand across cultures: the case of IKEA". International Journal of Retail \& Distribution Management, Vol. 39 No. 8, pp.598-618.

Tasci, A. D., and Guillet, B. D. (2016). "Hospitality cobranding: An experimental investigation of enhancement and erosion in consumer-based brand equity". International Journal of Hospitality \& Tourism Administration, Vol. 17 No. 4, pp.397428.

Tavassoli, N. T., Sorescu, A., and Chandy, R. (2014). "Employee-based brand equity: Why firms with strong brands pay their executives less". Journal of Marketing Research, Vol. 51 No. 6, pp.676-690.

Taylor, S., Hunter, G. and Lindberg, D. (2007), "Understanding (customer-based) brand equity in financial services", Journal of Services Marketing, Vol. 21 No. 4, pp. 241-252. 
Tsaur, S. H., and Ku, P. S. (2019). "The Effect of Tour Leaders' Emotional Intelligence on Tourists' Consequences”. Journal of Travel Research, Vol. 58 No. 1, pp.63-76.

Wong, I. A. (2016). "Linking firms, employees, and customers: a multilevel research agenda for hospitality studies”. Cornell Hospitality Quarterly, Vol. 57 No. 1, pp.7-20.

Wong, T., and Wickham, M. (2015). "An examination of Marriott's entry into the Chinese hospitality industry: A Brand Equity perspective". Tourism Management, Vol. 48, pp.439-454.

Xie, L. S., Peng, J. M., and Huan, T. C. (2014). "Crafting and testing a central precept in service-dominant logic: Hotel employees' brand-citizenship behavior and customers' brand trust". International Journal of Hospitality Management, Vol. 42, pp.1-8.

Xie, L., Li, Y., Chen, S, and Huan, T. (2016). "Triad theory of hotel managerial leadership, employee brand-building behavior, and guest images of luxury-hotel brands", International Journal of Contemporary Hospitality Management, Vol. 28 No. 9, pp.1826-1847.

Xiong, L., King, C., and Piehler, R. (2013). "That's not my job: Exploring the employee perspective in the development of brand ambassadors". International Journal of Hospitality Management, Vol. 35, pp.348-359.

Yao, B., Qiu, R. T. R., Fan, D.X.F., Liu, A. and Buhalis, D. (2019). "Standing out from the crowd - An exploration of signal attributes of Airbnb listings". International Journal of Contemporary Hospitality Management. DOI:10.1108/IJCHM-02-2019-0106 
Table 1. Demographics of Respondents

\begin{tabular}{lcc}
\hline \multicolumn{1}{c}{ Demographics } & $\begin{array}{c}\text { Executives (\%) } \\
(\mathbf{N = 9 2 5 )}\end{array}$ & $\begin{array}{c}\text { Employees (\%) } \\
(\mathbf{N = 1 , 9 7 8 )}\end{array}$ \\
\hline Gender & & \\
Male & 55.4 & 59.2 \\
Female & 44.6 & 40.8 \\
Age & & \\
Below 25 & n.a. & 29.1 \\
25-34 & n.a. & 48.5 \\
35-44 & n.a. & 16.8 \\
45-54 & n.a. & 5.4 \\
55 or above & n.a. & 0.1 \\
Education & & \\
Junior high school & 2.7 & 8.0 \\
Senior high school & 8.8 & 25.6 \\
Associate degree & 44.1 & 39.2 \\
Bachelor degree & 39.2 & 26.2 \\
Master's or above & 5.2 & 1.0 \\
Working Experience & & \\
(Managerial/Employee positions) & & 45.2 \\
Below 5 & 67.2 & 25.9 \\
5-9 & 20.8 & 13.4 \\
10-14 & 8.7 & 6.6 \\
15-19 & 2.8 & 8.9 \\
20 or above & 0.6 & \\
\hline
\end{tabular}


Table 2. Confirmatory Factor Analyses Results

\begin{tabular}{|c|c|c|c|}
\hline Measures & Factor loading & t-statistic & $\operatorname{Mean}^{\mathrm{b}}(\mathrm{SD})$ \\
\hline Executive Brand Identity & \multicolumn{3}{|c|}{$(\mathrm{AVE}=0.841$, Composite Reliability $=0.981)$} \\
\hline We have differentiated our brand from the competitors. & 0.807 & 99.917 & $6.463(0.081)$ \\
\hline We have created a brand that has unique personality and is memorable. & 0.873 & 156.732 & $6.342(0.105)$ \\
\hline We know the direction of our future development. & 0.951 & 390.897 & $6.299(0.116)$ \\
\hline We know what needs to be done to achieve our future goals. & 0.935 & 304.326 & $6.398(0.115)$ \\
\hline Our brand represents the values of our organization. & 0.939 & 319.125 & $6.276(0.126)$ \\
\hline Our marketing is guided by our brand values. & 0.946 & 353.766 & $6.328(0.108)$ \\
\hline We strive for the integration of our marketing activities. & 0.935 & 299.977 & $6.391(0.112)$ \\
\hline Our office layout, logo, and clothing represent our brand values. & 0.943 & 345.148 & $6.250(0.139)$ \\
\hline Physical Facility Quality & \multicolumn{3}{|c|}{$(\mathrm{AVE}=0.891$, Composite Reliability $=0.977)$} \\
\hline \multicolumn{4}{|l|}{$\begin{array}{l}\text { Compared to competitors, to what extend your hotel performs better in the following area in terms of } \\
\text { physical facilities: }\end{array}$} \\
\hline Guestroom & 0.930 & 293.925 & $6.258(0.226)$ \\
\hline Lobby & 0.949 & 397.486 & $6.266(0.129)$ \\
\hline $\mathrm{F} \& \mathrm{~B}$ & 0.970 & 653.896 & $6.222(0.203)$ \\
\hline Meeting \& banquet & 0.953 & 434.114 & $6.258(0.213)$ \\
\hline Commercial (business center, ATM and pay phone, retail shops) & 0.900 & 205.089 & $6.131(0.212)$ \\
\hline Gym \& recreation & 0.924 & 272.133 & $6.257(0.186)$ \\
\hline Public area & 0.982 & 994.301 & $6.304(0.162)$ \\
\hline Front office & 0.966 & 578.946 & $6.329(0.145)$ \\
\hline Back office & 0.917 & 248.065 & $6.280(0.176)$ \\
\hline CBBE & \multicolumn{3}{|c|}{$(\mathrm{AVE}=0.929$, Composite Reliability $=0.985)$} \\
\hline Our brand is better known than our most important competitors'. & 0.974 & 660.577 & $6.377(0.260)$ \\
\hline The quality of our brand as perceived by our customers is higher than our competitors'. & 0.978 & 743.355 & $6.360(0.243)$ \\
\hline Our brand is 'friendlier' than our competitors'. & 0.956 & 442.478 & $6.362(0.186)$ \\
\hline A high proportion of the products under our umbrella brand are leaders in their respective markets. & 0.948 & 379.798 & $6.338(0.156)$ \\
\hline Employee Brand Internalization & \multicolumn{3}{|c|}{$(\mathrm{AVE}=0.812$, Composite Reliability $=0.874)$} \\
\hline
\end{tabular}


Training programs equip me with appropriate skills to fulfill brand promises according to our brand standards.

I am often attracted by the colorful promotional materials of the hotel.

My hotel uses effective communications to notify employees of relevant information.

I am encouraged to propose innovative or better ways of doing things.

Training programs inspire me to fulfill the brand promises.

I like the orientation and brand handbook of my hotel.

I am clearly aware of the brand's mission after group meeting/training.

I clearly understand my role in the hotel after the group meeting.

All the basic information on services required based on the brand expectation is included in the briefing.

The brand mission and promises are continuously enhanced by meetings/briefing.

\section{EBBE}

My colleagues want to work for the brand under our company in the future.

In private conversation with potential customers, my colleagues are willing to...

communicate the same brand value in the long term.

behave consistently with other manifestations of our branding efforts (e.g., advertising, exhibitions or the website).

make no statements that are inconsistent with our brand communication in the media.

emphasize the objective/technical standards (e.g., quality, reliability) and emotional/symbolic aspects (e.g., trust, friendliness) of our brand.

underline the advantages of our brand in comparison to our competitors.

My colleagues are aware of the fact that everything they say or do can affect the brand image.

My colleagues' behaviors are always consistent with the brand values, even when they are not monitored nor rewarded for doing so.

My colleagues work diligently and are concerned about quality when it positively affects our brand image.

My colleagues would voluntarily work overtime if that could positively affect our brand image (e.g., to complete a customer's order on time).

My colleagues would recommend our brand to friends/relatives in private conversations.

My colleagues try hard to communicate our brand values to new colleagues (e.g., by way of informal chats or volunteering for a mentoring role).

179.201

132.926

210.194

180.435

236.714

209.184

251.437

231.643

214.351

212.898

0.908

$(\mathrm{AVE}=0.692$, Composite Reliability $=0.736)$

$\begin{array}{lcl}0.742 & 70.766 & 6.134(1.259) \\ 0.785 & 86.413 & 6.301(0.830) \\ 0.824 & 107.183 & 6.362(0.711) \\ 0.734 & 68.046 & 6.432(0.748) \\ 0.864 & 140.542 & 6.434(0.607) \\ 0.787 & 87.677 & 6.420(0.685)\end{array}$

0.949

338.430

$6.422(0.527)$

$6.438(0.594)$

$6.363(0.721)$

$6.418(0.604)$

$6.380(0.661)$

$6.402(0.645)$

$6.430(0.560)$

$6.414(0.586)$

$6.423(0.557)$

.

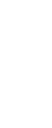


To better meet the customers' expectation of our brand...

my colleagues actively seek customer feedback.

my colleagues engage in voluntary self-development by reading manuals, guidebooks or professional

magazines.

my colleagues participate in retraining and skill enhancement workshops.

my colleagues forward customer feedback or report problems to the people in charge in a timely manner.

my colleagues proactively develop new product/service ideas and suggest improvements.

Note: According to Baumgarth and Schmidt (2010), items in each of the shaded areas are averaged into one index and used as a single item in the analysis. 
Table 3. Construct Correlations

\begin{tabular}{|c|c|c|c|c|c|}
\hline & \multicolumn{5}{|c|}{ Correlations } \\
\hline & $\begin{array}{c}\text { Executive Brand } \\
\text { Identity } \\
\end{array}$ & $\begin{array}{c}\text { Physical Facility } \\
\text { Quality }\end{array}$ & $\mathrm{CBBE}$ & $\begin{array}{c}\text { Brand } \\
\text { Internalization }\end{array}$ & $\mathrm{EBBE}$ \\
\hline Executive Brand Identity & 1.000 & & & & \\
\hline Physical Facility Quality & 0.084 & 1.000 & & & \\
\hline $\mathrm{CBBE}$ & 0.909 & 0.095 & 1.000 & & \\
\hline Brand Internalization & 0.084 & 0.624 & 0.079 & 1.000 & \\
\hline EBBE & 0.122 & 0.822 & 0.130 & 0.599 & 1.000 \\
\hline
\end{tabular}



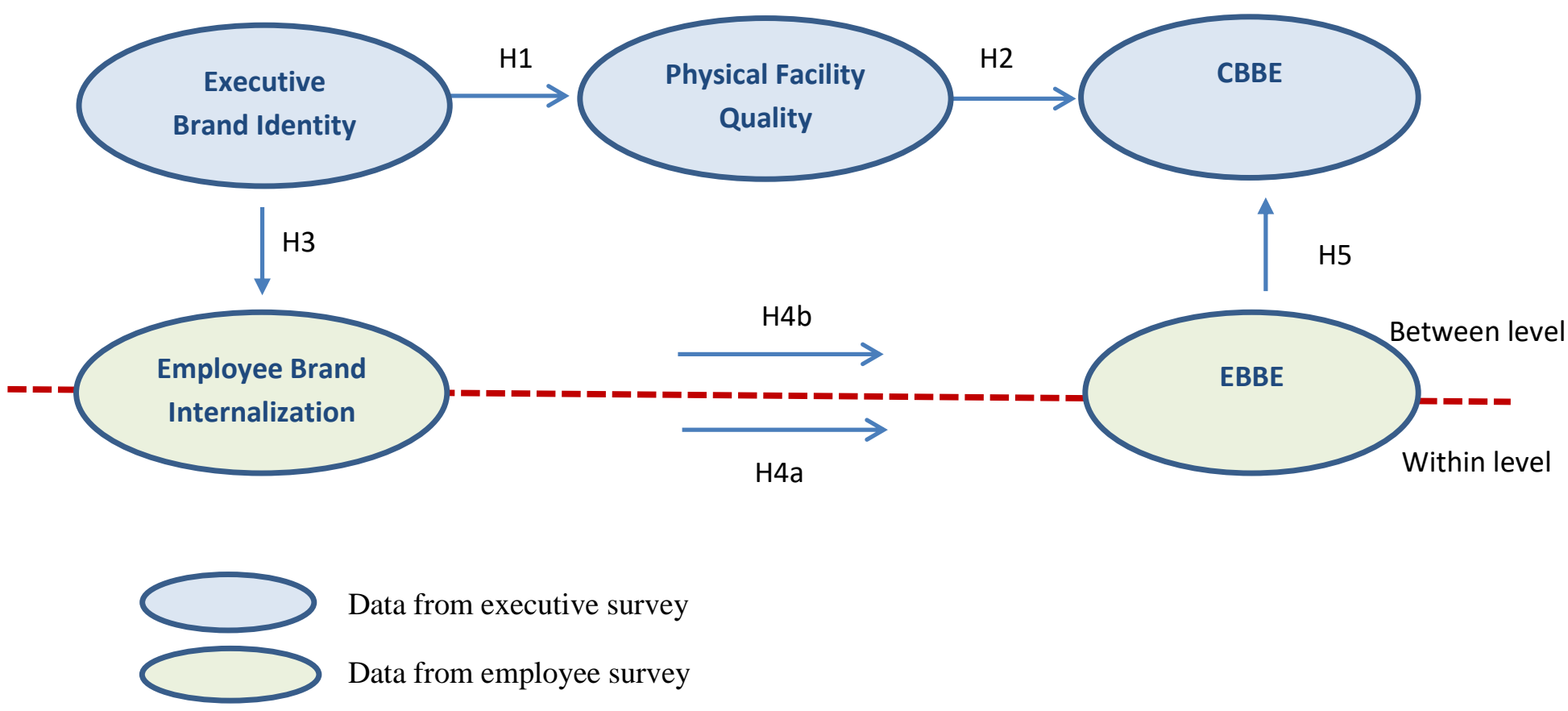

Figure 1. Proposed Conceptual Model with Hypotheses

Note: In multilevel SEM, the lower individual-level relationship is termed "within level" and higher organization-level relationship termed "between level". The dotted line separates the within and between levels in the model. 


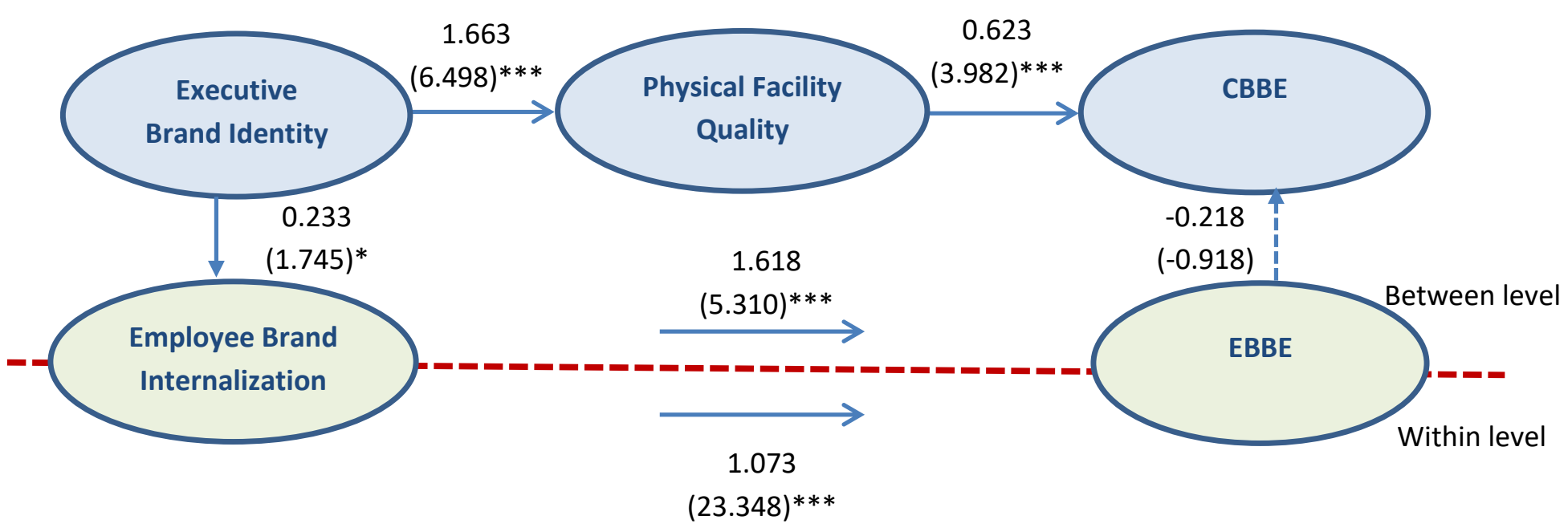

Figure 2. Structural Model with Standardized Paths

Note: Figures in parenthesis are Z-statistics. ${ }^{*}, * *$ and $* * *$ indicate significant at $10 \%, 5 \%$ and $1 \%$, respectively. 